\title{
Receptor Gene
}

National Cancer Institute

\section{Source}

National Cancer Institute. Receptor Gene. NCI Thesaurus. Code C20103.

Receptor Genes encode cell surface or cytoplasmic receptor proteins that each bind to specific signaling factors (such as a hormone, antigen, or neurotransmitter) causing a conformational and functional change in the ligand-bound receptor, altering its interaction with target molecules and leading to changes in cellular physiology through modification of the activity of one or more signal transduction pathways. 